\title{
Toxic shock syndrome with a cytokine storm caused by Staphylococcus simulans: a case report
}

\author{
Ken Goda ${ }^{1,2}$, Tsuneaki Kenzaka ${ }^{1,2^{*}}$ (D, Masahiko Hoshijima', Akihiro Yachie ${ }^{3}$ and Hozuka Akita ${ }^{1}$
}

\begin{abstract}
Background: Exotoxins secreted from Staphylococcus aureus or Streptococcus pyogenes act as superantigens that induce systemic release of inflammatory cytokines and are a common cause of toxic shock syndrome (TSS). However, little is known about TSS caused by coagulase-negative staphylococci (CoNS) and the underlying mechanisms. Here, we present a rare case of TSS caused by Staphylococcus simulans (S. simulans).
\end{abstract}

Case presentation: We report the case of a 75-year-old woman who developed pneumococcal pneumonia and bacteremia from S. simulans following an influenza infection. The patient met the clinical criteria for probable TSS, and her symptoms included fever of $39.5^{\circ} \mathrm{C}$, diffuse macular erythroderma, conjunctival congestion, vomiting, diarrhea, liver dysfunction, and disorientation. Therefore, the following treatment was initiated for bacterial pneumonia complicating influenza A with suspected TSS: meropenem ( $1 \mathrm{~g}$ every $8 \mathrm{~h}$ ), vancomycin ( $1 \mathrm{~g}$ every $12 \mathrm{~h}$ ), and clindamycin (600 mg every $8 \mathrm{~h}$ ). Blood cultures taken on the day after admission were positive for CoNS, whereas sputum and pharyngeal cultures grew Streptococcus pneumoniae (Geckler group 4) and methicillinsensitive S. aureus, respectively. However, exotoxins thought to cause TSS, such as TSS toxin-1 and various enterotoxins, were not detected. The patient's therapy was switched to cefazolin ( $2 \mathrm{~g}$ every $8 \mathrm{~h}$ ) and clindamycin ( $600 \mathrm{mg}$ every $8 \mathrm{~h}$ ) for 14 days based on microbiologic test results. She developed desquamation of the fingers on hospital day 8 and was diagnosed with TSS. Conventional exotoxins, such as TSST-1, and S. aureus enterotoxins were not detected in culture samples. The serum levels of inflammatory cytokines, such as neopterin and IL-6, were high. CD8+ T cells were activated in peripheral blood. V $32+$ population activation, which is characteristic for TSST-1, was not observed in the $\mathrm{V} \beta$ usage of $\mathrm{CD} 8+\mathrm{T}$ cells in $\mathrm{T}$ cell receptor $\mathrm{V} \beta$ repertoire distribution analysis.

Conclusions: We present a case of $S$. simulans-induced TSS. Taken together, we speculate that no specific exotoxins are involved in the induction of TSS in this patient. A likely mechanism is uncontrolled cytokine release (i.e., cytokine storm) induced by non-specific immune reactions against CoNS proliferation.

Keywords: Coagulase-negative staphylococcus, Cytokine storm, Staphylococcus simulans, Toxic shock syndrome

\footnotetext{
* Correspondence: smile.kenzaka@jichi.ac.jp

${ }^{1}$ Department of Internal Medicine, Hyogo Prefectural Tamba Medical Center, 2002-7 Iso, Hikami-cho, Tamba 669-3495, Japan

${ }^{2}$ Division of Community Medicine and Career Development, Kobe University Graduate School of Medicine, 2-1-5 Arata-cho, Hyogo-ku, Kobe 652-0032, Japan

Full list of author information is available at the end of the article
}

(C) The Author(s). 2021 Open Access This article is licensed under a Creative Commons Attribution 4.0 International License, which permits use, sharing, adaptation, distribution and reproduction in any medium or format, as long as you give appropriate credit to the original author(s) and the source, provide a link to the Creative Commons licence, and indicate if changes were made. The images or other third party material in this article are included in the article's Creative Commons licence, unless indicated otherwise in a credit line to the material. If material is not included in the article's Creative Commons licence and your intended use is not permitted by statutory regulation or exceeds the permitted use, you will need to obtain permission directly from the copyright holder. To view a copy of this licence, visit http://creativecommons.org/licenses/by/4.0/ The Creative Commons Public Domain Dedication waiver (http://creativecommons.org/publicdomain/zero/1.0/) applies to the data made available in this article, unless otherwise stated in a credit line to the data. 


\section{Background}

Toxic shock syndrome (TSS) caused by a Staphylococcus aureus infection is a relatively rare complication of influenza [1]. The diagnostic criteria defined by the Council of State and Territorial Epidemiologists of the United States includes fever $\left(38.9^{\circ} \mathrm{C}\right.$ or higher), diffuse erythematous dermatosis, desquamation (1-2 weeks after the onset of rash), hypotension (systolic blood pressure $<90 \mathrm{mmHg}$ ), and multi-system involvement (three or more organ systems) [2]. Exoproteins associated with $S$. aureus act as superantigens. They non-selectively bind to MHC class II antigens on antigen-presenting cells, activate a large number of $\mathrm{T}$ cells through $\mathrm{T}$-cell receptor interaction, and then induce the secretion of cytokines [3]. TSST-1 and a series of enterotoxins have been reported as such superantigens [4].

However, little is known about TSS caused by coagulase-negative staphylococci (CoNS) $[5,6]$. It remains to be determined how TSS is induced by the CoNS infection. An immune reaction to the proliferation of CoNS organisms that causes cytokine activation has been proposed as an underlying mechanism [5].

Here, we report the case of a patient with TSS caused by Staphylococcus simulans (S. simulans), a CoNS species, after pneumococcal pneumonia associated with influenza.

\section{Case presentation}

A 75-year-old woman, who was being treated with prednisolone $5 \mathrm{mg} /$ day for polymyalgia rheumatica, presented with anorexia and general malaise for 3 days and then developed vomiting and diarrhea. She experienced difficulty moving her body, and her consciousness deteriorated. The patient was brought to our hospital on an ambulance. The consciousness level on admission, body temperature, blood pressure, pulse rate, respiratory rate, and peripheral oxygen saturation were E3V4M6, $39.5^{\circ} \mathrm{C}$, $153 / 88 \mathrm{mmHg}, 124$ beats/minute, 25 breaths/minute, and $90 \%$ (with oxygen mask $6 \mathrm{~L} / \mathrm{min}$ ), respectively. Her bulbar conjunctiva was congested on both sides, and coarse crackles were heard in the right lung field. Reticular dermatosis was found on both of her lower legs, and erythematous dermatosis was observed on the lower side of the back. Laboratory blood tests on admission showed elevated inflammatory markers (white blood cell count and C-reactive protein), creatine phosphokinase, and liver aminotransferase. Further, a rapid influenza diagnostic test was positive for influenza A (Table 1). Chest computed tomography (CT) showed diffuse airspace opacification in the right middle lobe (Fig. 1). Head CT demonstrated a slight fluid collection in the right upper sinus suggesting sinusitis.

Her clinical signs and symptoms fulfilled three out of five clinical criteria of TSS with a fever of $38.9^{\circ} \mathrm{C}$ or
Table 1 Laboratory data at admission

\begin{tabular}{lll}
\hline Parameter & Recorded value & Reference value \\
\hline White blood cell count & $5.37 \times 10^{3} / \mu \mathrm{L}$ & $4.50-7.50 \times 10^{3} / \mathrm{\mu L}$ \\
Neutrophils & $89.6 \%$ & $42-74 \%$ \\
Lymphocytes & $5.6 \%$ & $18-50 \%$ \\
Hemoglobin & $12.6 \mathrm{~g} / \mathrm{dL}$ & $11.3-15.2 \mathrm{~g} / \mathrm{dL}$ \\
Hematocrit & $37.6 \%$ & $36-45 \%$ \\
Platelets & $179 \times 10^{3} / \mu \mathrm{L}$ & $130-350 \times 10^{3} / \mu \mathrm{L}$ \\
C-reactive protein & $5.0 \mathrm{mg} / \mathrm{dL}$ & $\leq 0.60 \mathrm{mg} / \mathrm{dL}$ \\
Total protein & $6.5 \mathrm{~g} / \mathrm{dL}$ & $6.9-8.4 \mathrm{~g} / \mathrm{dL}$ \\
Albumin & $3.3 \mathrm{~g} / \mathrm{dL}$ & $3.9-5.1 \mathrm{~g} / \mathrm{dL}$ \\
Aspartate aminotransferase & $134 \mathrm{U} / \mathrm{L}$ & $11-30 \mathrm{U} / \mathrm{L}$ \\
Alanine aminotransferase & $156 \mathrm{U} / \mathrm{L}$ & $4-30 \mathrm{U} / \mathrm{L}$ \\
Lactate dehydrogenase & $323 \mathrm{U} / \mathrm{L}$ & $109-216 \mathrm{U} / \mathrm{L}$ \\
Creatine phosphokinase & $404 \mathrm{U} / \mathrm{L}$ & $40-150 \mathrm{U} / \mathrm{L}$ \\
Blood nitrogen urea & $20.2 \mathrm{mg} / \mathrm{dL}$ & $8-20 \mathrm{mg} / \mathrm{dL}$ \\
Creatinine & $0.58 \mathrm{mg} / \mathrm{dL}$ & $0.63-1.03 \mathrm{mg} / \mathrm{dL}$ \\
Sodium & $136 \mathrm{mEq} / \mathrm{L}$ & $136-148 \mathrm{mEq} / \mathrm{L}$ \\
Potassium & $3.2 \mathrm{mEq} / \mathrm{L}$ & $3.6-5.0 \mathrm{mEq} / \mathrm{L}$ \\
Glucose & $166 \mathrm{mg} / \mathrm{dL}$ & $70-109 \mathrm{mg} / \mathrm{dL}$ \\
Rapid influenza test & Positive for type A & \\
\hline
\end{tabular}

higher, diffuse erythroderma, and multisystem involvement (conjunctival congestion, gastrointestinal symptoms of vomiting and diarrhea, hepatic dysfunction, and disorientation). At this time point, she had not developed desquamation yet and had no hypotension. Therefore, the patient was clinically diagnosed with influenza with bacterial pneumonia and potential TSS, and her treatment was started with meropenem ( $1 \mathrm{~g}$ every $8 \mathrm{~h}$ ), vancomycin $(1 \mathrm{~g}$ every $12 \mathrm{~h}$, therapeutic drug monitoring: $\geq 15 \mu \mathrm{g} / \mathrm{mL}$ ), and clindamycin $(600 \mathrm{mg}$ every $8 \mathrm{~h}$ ).

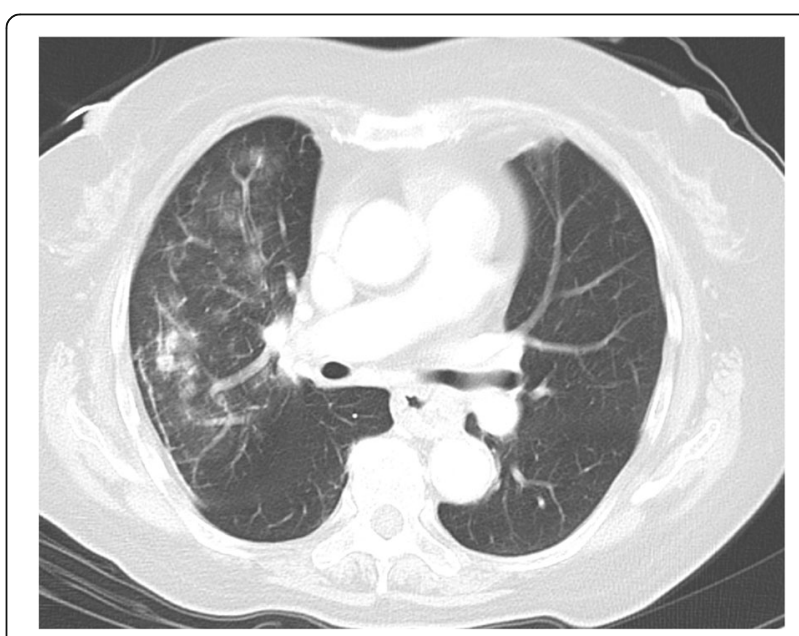

Fig. 1 Chest computed tomography on admission 
The next day, S. simulans, a CoNS strain, was detected in both sets of blood cultures. Furthermore, pneumococci and methicillin-sensitive Staphylococcus aureus (MSSA) were identified in sputum cultures (Geckler 4 group) and pharyngeal cultures (small number of colonies), respectively. Exotoxins, such as TSST-1, and staphylococcal enterotoxins (type A, B, C, and D), which are known to cause TSS, were not detected in culture samples of MSSA and S. simulans. We used the reversed passive latex agglutination method to evaluate the exotoxins and enterotoxins; the minimum detection sensitivity of sensitized latex using this method was found to be $1-2 \mathrm{ng} / \mathrm{mL}$. We changed the antimicrobial therapy to cefazolin (1 g q8h) and clindamycin (600 mg q8h), based on microbiologic test results, and this therapy was administered for 14 days. Finger desquamation appeared on the 8th day of hospitalization, fulfilling four out of five clinical criteria for TSS. Therefore, we diagnosed the case as probable TSS.

Serum levels of inflammatory cytokines were high: neopterin $62 \mathrm{mmol} / \mathrm{L}$ (reference range, $\leq 5 \mathrm{mmol} / \mathrm{L}$ ) and IL-6 $38 \mathrm{pg} / \mathrm{mL}$ (reference range, $\leq 5 \mathrm{pg} / \mathrm{mL}$ ). Lymphocyte subpopulation distribution was then analyzed in peripheral blood (Fig. 2), showing prominent CD57 expression in CD8+ $\mathrm{T}$ cells, suggesting strong activation of this $\mathrm{T}$ lymphocyte subset.

Furthermore, $\mathrm{T}$ cell receptor (TCR) V $\beta$ repertoire distribution analysis was carried out (Fig. 3). A specific subset of CD8+ T cells, including V $\beta 7.2$ and V $\beta 14$ cells, was increased, indicating the oligoclonal activation of CD8+ $\mathrm{T}$ cells likely due to antigen exposure. However, the distribution of CD4+ T cell TCR V $\beta$ repertoire was normal. The activation of $\mathrm{V} \beta 2+$ population, which is characteristic for TSST-1, was not observed.

\section{Discussion and conclusions}

The occurrence of TSS by CoNS is extremely rare, and only a few cases have been reported $[5,6]$. The current patient was diagnosed with probable TSS (non-streptococcal), as she fulfilled the five diagnostic criteria proposed by the Council of State and Territorial Epidemiologists (USA) and Centers for Disease Control and Prevention (US). Furthermore, the underlying mechanism not only involves superantigens but also interactions among bacterial cell wall components and monocytes, leading to the release of cytokine mediators [5].

Generally, TSS is caused by S. aureus infection. In the common forms of TSS, exotoxins, such as TSST-1, and a series of staphylococcal enterotoxins non-selectively act as superantigens on MHC class II antigens on antigen-presenting cells and TCR on T-cells, causing the activation of a large number of $\mathrm{T}$ cells and systemic secretion of cytokines [3]. Known exotoxins causing TSS were undetectable in the current case using the reversed passive latex agglutination method.

S. simulans is a residential type of CoNS in animals, such as cattle, sheep, and goats, and it is sometimes pathogenic to humans [7]. There have been reports of

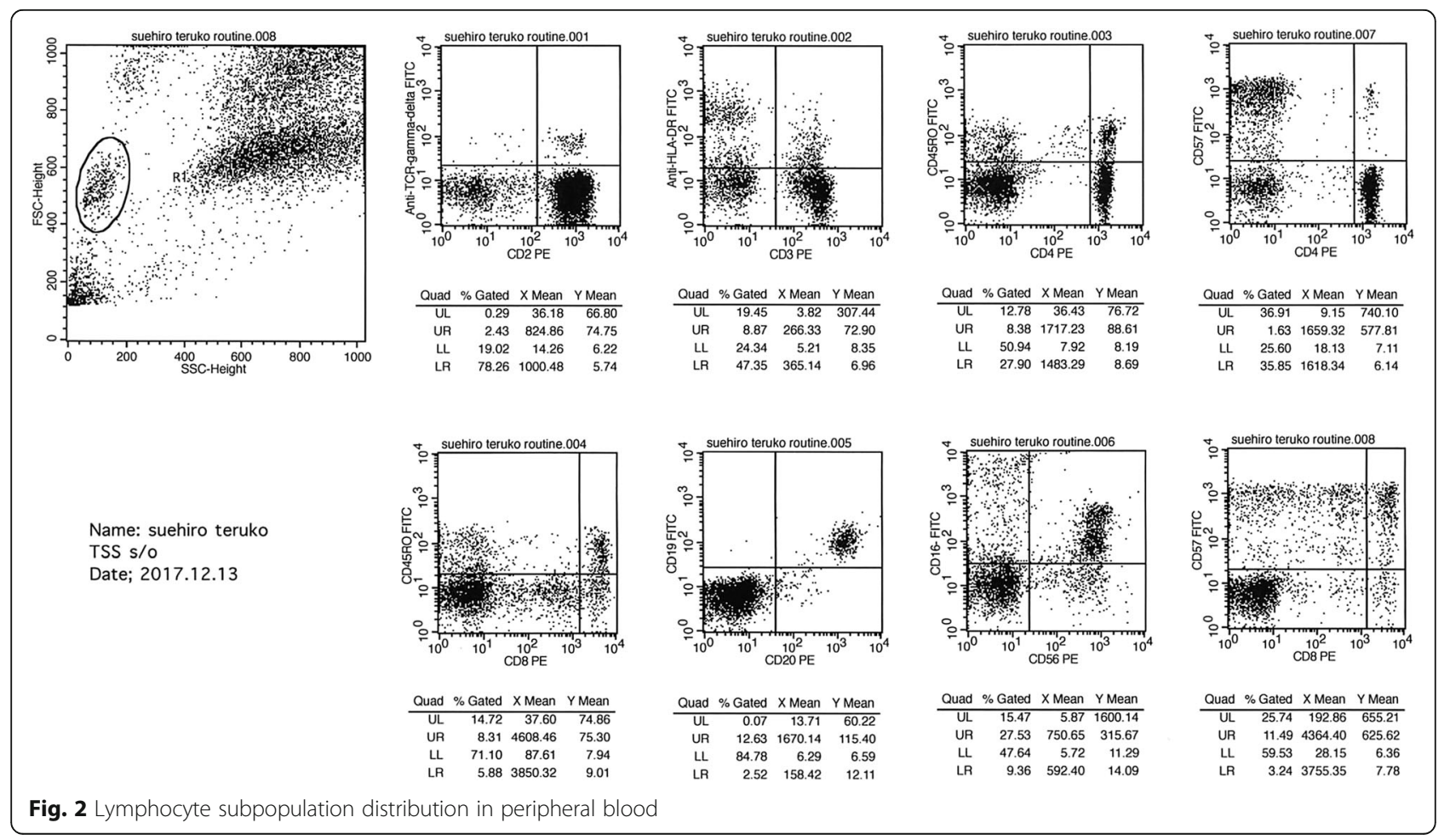




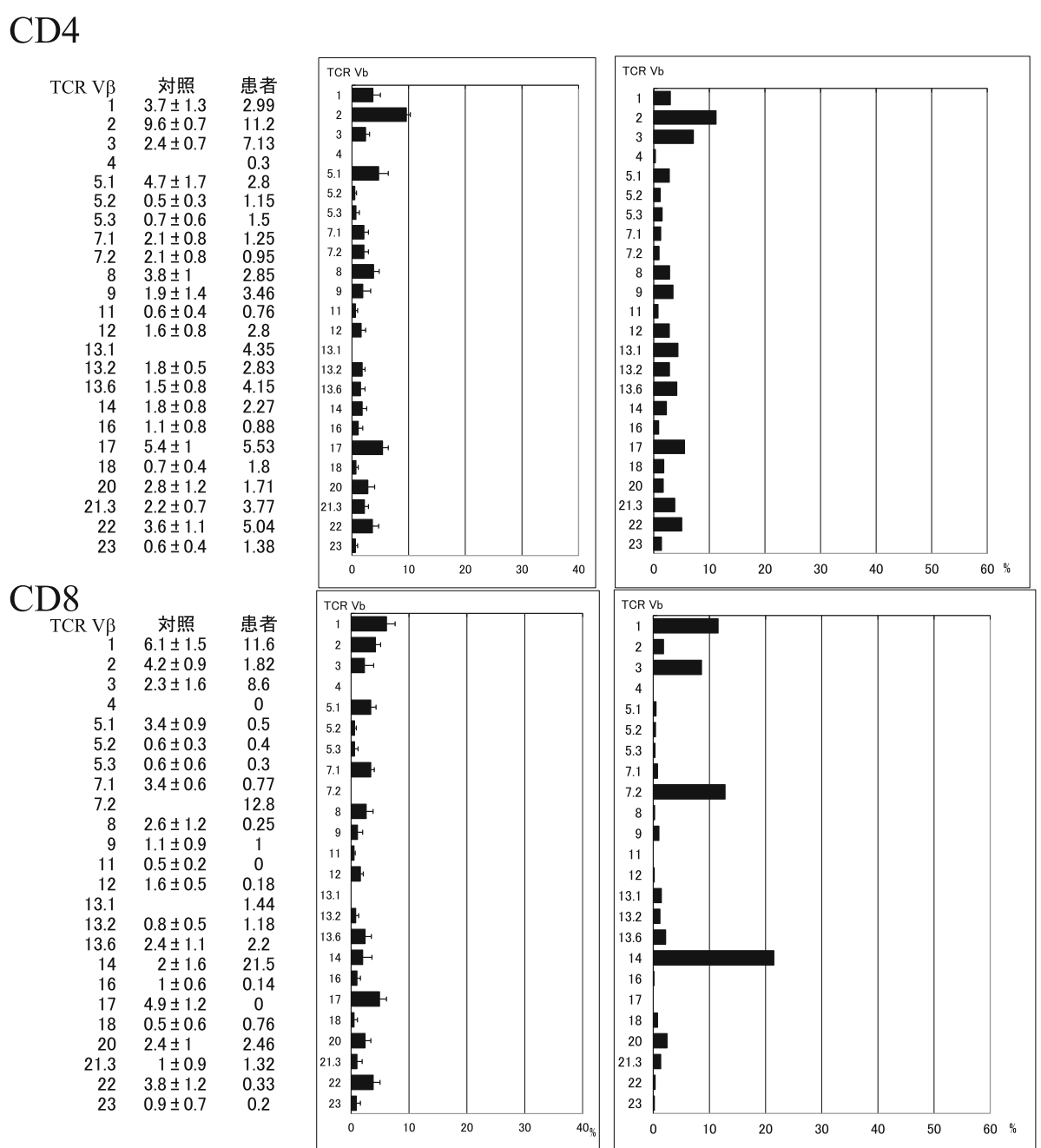

Fig. $3 T$ cell receptor (TCR) $\vee \beta$ repertoire distribution analysis in peripheral blood

bacteremia, infective endocarditis, and cellulitis [8]. It has been reported that blood cultures become positive within $30 \mathrm{~h}$ from culture initiation, when CoNS is the causative organism [9]. Contrarily, $46.7 \%$ of $S$. aureus are exotoxin-producing strains, and only $26.7 \%$ of CoNS strains produce exotoxins [10]. Whether exotoxins secreted by CoNSs are capable of inducing TSS remains unknown.

In the acute phase of common staphylococcal TSS, $\mathrm{V} \beta 2$-positive $\mathrm{T}$ cells increase more than several times compared to the normal values stimulated mainly by the exotoxin TSST-1 [11]. We observed relatively selective increases in V $\beta 7.2$ and $V \beta 14$-positive CD8+ $T$ cells in the current patient. This type of TCR V $\beta$ selectivity has not been linked to known superantigens [12] and may be a unique response to some specific antigens. In fact, there has been no report on the analysis of the TCR V $\beta$ repertoire in a patient with TSS caused by CoNS.
In the current case, the levels of inflammatory cytokines, including neopterin and IL-6, were high, suggesting a strong activation of the immune system known as cytokine storm [13]. It remains to be determined how TSS is induced by CoNS infection. The distinct pattern of TCR V $\beta$ selectivity in the current case coordinates well with the negative results of TSST-1 and enterotoxin tests. A proposed mechanism has been that an immune reaction to the proliferation of CoNS organisms causes cytokine activation [5]. This warrants further studies investigating TCR V $\beta$ selectivity in TSS associated with CoNS.

In conclusion, we present a case of $S$. simulans-induced TSS. We speculate that no specific exotoxins were involved in the induction of TSS in this patient. A likely mechanism is the uncontrolled cytokine release (i.e., cytokine storm) induced by non-specific immune reactions against CoNS proliferation. 


\section{Abbreviations}

CoNS: Coagulase-negative staphylococcus; CT: Computed tomography; MSSA: Methicillin-sensitive Staphylococcus aureus; S. simulans: Staphylococcus simulans; TCR: T cell receptor; TSS: Toxic shock syndrome

\section{Acknowledgements}

We would like to thank Editage (www.editage.com) for English language editing.

\section{Authors' contributions}

KG and $\mathrm{MH}$ managed the case, and prepared and revised the manuscript. TK assisted with the preparation and revision of the manuscript. AY assisted with data analysis and revision of the manuscript. HA assisted with manuscript revision and prepared the figures. All co-authors approved the final manuscript as submitted and agree to be accountable for all aspects of the work. All co-authors take full responsibility for the integrity of the study and the final manuscript. The author(s) read and approved the final manuscript.

\section{Funding}

Not applicable.

\section{Availability of data and materials}

Data sharing is not applicable to this article as no datasets were generated or analyzed during the current study.

\section{Ethics approval and consent to participate}

Not applicable.

\section{Consent for publication}

Written informed consent was obtained from the patient for the publication of this case report and accompanying images. A copy of the written consent is available for review by the Editor of this journal.

\section{Competing interests}

The authors declare that they have no competing interests.

\section{Author details}

'Department of Internal Medicine, Hyogo Prefectural Tamba Medical Center, 2002-7 Iso, Hikami-cho, Tamba 669-3495, Japan. ${ }^{2}$ Division of Community Medicine and Career Development, Kobe University Graduate School of Medicine, 2-1-5 Arata-cho, Hyogo-ku, Kobe 652-0032, Japan. ${ }^{3}$ Department of Pediatrics, Kanazawa University, 13-1, Takaramachi, Kanazawa 920-8641, Japan.

Received: 25 May 2020 Accepted: 22 December 2020

Published online: 06 January 2021

\section{References}

1. MacDonald KL, Osterholm MT, Hedberg CW, Schrock CG, Peterson GF, Jentzen JM, et al. Toxic shock syndrome. A newly recognized complication of influenza and influenzalike illness. JAMA. 1987;257:1053-8.

2. Centers for Disease Control and Prevention. Toxic shock syndrome (other than streptococcal) (TSS) 2011 case definition. https://wwwn.cdc.gov/nndss/ conditions/toxic-shock-syndrome-other-than-streptococcal/case-definition/2 011/reference7/.

3. Söderquist B, Källman J, Holmberg H, Vikerfors T, Kihlström E. Secretion of IL-6, IL-8 and G-CSF by human endothelial cells in vitro in response to Staphylococcus aureus and staphylococcal exotoxins. APMIS. 1998;106:1157-64.

4. Spaulding AR, Salgado-Pabón W, Kohler PL, Horswill AR, Leung DYM, Schlievert PM. Staphylococcal and streptococcal superantigen exotoxins. Clin Microbiol Rev. 2013;26:42247.

5. Lina G, Fleer A, Etienne J, Greenland TB, Vandenesch F. Coagulase-negative staphylococci isolated from two cases of toxic shock syndrome lack superantigenic activity, but induce cytokine production. FEMS Immunol Med Microbiol. 1996;13:81-6.

6. Crass BA, Bergdoll MS. Involvement of coagulase-negative staphylococci in toxic shock syndrome. J Clin Microbiol. 1986;23:43-5.

7. Kloos WE, Bannerman TL. Staphylococcus and Micrococcus. In Murray PR, et al.: eds. Manual of Clinical Microbiology 7th ed. Washinton DC: ASM Press; 1999. p. 264-82.
8. Shields BE, Tschetter AJ, Wanat KA. Staphylococcus simulans: an emerging cutaneous pathogen. JAAD Case Rep. 2016;2:428-9.

9. Ohshiro T, Uchima K, Ohshiro R, Ohshiro O, Taira H, Oyakawa K. Proposal of criteria for determining clinically significant bacteria using the time to positive culture of coagulase-negative staphylococci in blood cultures. $J$ Japan Soc Clin Microbiol. 2004;14:177-82.

10. da Cunha ML, Calsolari RA, Júnior JP. Detection of enterotoxin and toxic shock syndrome toxin 1 genes in Staphylococcus, with emphasis on coagulase-negative staphylococci. Microbiol Immunol. 2007;51:381-90.

11. Choi Y, Laferty JA, Clements JR, Todd JK, Gelfand EW, Kappler J, et al. Selective expansion of $\mathrm{T}$ cells expressing $\mathrm{V}$ beta 2 in toxic shock syndrome. J Exp Med. 1990;172:981-4

12. Alouf JE, Müller-Alouf H. Staphylococcal and streptococcal superantigens: molecular, biological and clinical aspects. Int J Med Microbiol. 2003;292:429-40.

13. Shimizu M, Yokoyama T, Yamada K, Kaneda H, Wada H, Wada T, et al. Distinct cytokine profiles of systemic-onset juvenile idiopathic arthritisassociated macrophage activation syndrome with particular emphasis on the role of interleukin-18 in its pathogenesis. Rheumatology (Oxford). 2010; 49:1645-53.

\section{Publisher's Note}

Springer Nature remains neutral with regard to jurisdictional claims in published maps and institutional affiliations.

\section{Ready to submit your research? Choose BMC and benefit from:}

- fast, convenient online submission

- thorough peer review by experienced researchers in your field

- rapid publication on acceptance

- support for research data, including large and complex data types

- gold Open Access which fosters wider collaboration and increased citations

- maximum visibility for your research: over $100 \mathrm{M}$ website views per year

At BMC, research is always in progress.

Learn more biomedcentral.com/submissions 